\title{
Time-Window of Progesterone Neuroprotection After Stroke and Its Underlying Molecular Mechanisms
}

\author{
Weiyan Cai ${ }^{1}$, Masahiro Sokabe ${ }^{2}$ and Ling Chen ${ }^{1,2}$ \\ ${ }^{1}$ Department of Physiology, Nanjing Medical University, Jiangsu, \\ 2Department of Physiology, Nagoya University Graduate School of Medicine, \\ Tsurumai, Nagoya, \\ ${ }^{1}$ China, \\ ${ }^{2}$ Japan
}

\section{Introduction}

Evidence exists for a gender difference in the vulnerability to either stroke or traumatic brain injury (TBI) in humans. For example, pre-menopausal women with the high serum levels of ovarian hormones estrogen (E2) and progesterone (P4) have a lower risk of stroke (Kannel et al., 1994; Sacco et al., 1997) and a better outcome following stroke (Thorvaldsen et al., 1995) or TBI (Groswasser et al., 1998) relative to men of the same age. After menopause, incidence of stroke in women increases abruptly (Wenger et al., 1993) coincident with decreases in the circulating levels of the ovarian steroid hormones, estrogen (E2) and progesterone (P4). Although clinical trial for TBI with P4 treatment has been well tolerated and giving improved outcomes (Wright et al., 2007; Stein et al., 2008), clinical trial with P4 treatment after cerebral stroke has yet to be initiated. There is increasing evidence that P4 exerts a potent neuroprotective effect against ischemia-induced brain injury in experimental models (Chen et al., 1999; Kumon et al., 2000; Morali et al., 2005; Sayeed et al., 2006) when administered either before insult or after the onset of reperfusion (Murphy et al., 2002; Sayeed et al., 2007). Furthermore, the administration of P4 promotes functional recovery after cerebral ischemia (Gibson \& Murphy, 2004; Sayeed et al., 2007). Important enough, a single injection of $\mathrm{P} 4(4 \mathrm{mg} / \mathrm{kg})$ conducted even $2 \mathrm{~h}$ after transient focal brain ischemia reduced cortical infarct volumes (Jiang et al., 1996). Our recent study (Cai et al., 2008) has demonstrated that in male rats a single injection of $\mathrm{P} 4(4 \mathrm{mg} / \mathrm{kg})$ at $1 \mathrm{~h}$ or $48 \mathrm{~h}$ prior to an experimental stroke shows protective effects against the ischemia-induced neuronal death and the deficits in spatial cognition and LTP induction. However, to date no systematic study has conducted concerning the effects of P4 against brain injury beyond $6 \mathrm{~h}$ following the onset of ischemia (Gibson et al., 2008). Therefore, the present study focused on the effective time-window of neuroprotection by $\mathrm{P} 4$ treatment, which would give useful information in treating stroke.

Effects of $\mathrm{P} 4$ on the brain generally involve three principle mechanisms, including regulation of gene expression, activation of intracellular signal cascades and modulation of 
neurotransmitter systems. P4 has been well known to affect transcription processes through the action on the classical nuclear progesterone's receptor (P4R) followed by multiple interactions with DNA and sequence-specific transcription factors (Beato et al., 1995; Guerra-Araiza et al., 2003). The activation of P4R regulates the expression of anti-apoptotic proteins such as bcl-2, and pro-apoptotic genes including bax and bad and caspase-3 (Schlesinger and Saito, 2006). On the transcriptional level, P4 reduces both the nuclear concentration of NFKB and expression of NFKB target genes. P4 has been found to influence the activity of many signaling pathways so-called "nongenomic mechanisms" via a membrane-associated P4R (mP4R) that lacks functional DNA-binding domain (GuerraAraiza et al., 2009). Increasing evidence indicates that P4R activates Src-ERK signaling pathway which serves as an indicator of growth factor activity in mammalian breast cancer cells (Boonyaratanakornkit et al., 2008; Faivre and Lange, 2007). Cai et al. (2008) has demonstrated that P4 triggers P4R-mediated long-lasting $(>48 \mathrm{~h})$ phosphorylation of ERK1/2 and enhances the translocation of phosphorelated ERK2 into the nucleus. In addition, rapid effects of $\mathrm{P} 4$ is suggested to be mediated by membrane-associated P4binding protein 25-Dx (Meffre et al., 2005) to increase the level of phosphorylated Akt in neuronal cells (Singh et al., 2001). The membrane-associated P4R component 1 (PGRMC1) has been reported to elevate the level of Akt phosphorylation in breast cancer (Neubauer et al., 2008). P4 increases the phosphorylation of ERK and Akt, and the expression of the regulatory (p85) subunits of phosphoinositide-3 kinase (PI3K) in the brain (Guerra-Araiza et al., 2009). Furthermore, the P4's metabolite allopregnanolone (ALLO) potentiates the GABAergic synapse activity (Ardeshiri et al., 2006). Finally, much attention has recently been attracted to the antagonizing effects of P4 on sigma-1 $\left(\sigma_{1}\right)$ receptor (Maurice et al., 2006; Monnet \& Maurice, 2006).

The objective of the present study was to determine the P4-neuroprotective effect and its effective therapeutic time-window after transient cerebral ischemia. To this end, male animals subjected to $60 \mathrm{~min}$ middle cerebral artery occlusion (MCAO) were given a pair of intraperitoneal injections of P4 (4 mg/kg) separated by $8 \mathrm{~h}$ starting at 1, 24, 48, 72 or $96 \mathrm{~h}$ after the initiation of cerebral ischemia by middle cerebral artery occlusion (MCAO), and the size of brain infarct, loss of pyramidal neurons in the hippocampal CA1 and cognitive performance of the animals were assessed on $7^{\text {th }}$ day after MCAO. Using pharmacologic tools and western blot analysis, molecular mechanisms underlying the P4-neuroprotective effects against ischemia-induced cerebral injury were also investigated.

\section{Materials and methods}

\subsection{Experimental animals}

The present studies were approved by Animal Care and Ethical Committee of Nanjing Medical University. All procedures were in accordance with the guidelines of Institute for Laboratory Animal Research of Nanjing Medical University. Male Sprague-Dawley rats (200-250g, Oriental Bio Service Inc., Nanjing, China) before experiments were used throughout the study. We chose to use only adult male rats in the present study to avoide influence of the E2 effects (Nilsen and Brinton, 2003). Animal rooms were maintained on a 12:12 light-dark cycle starting at AM 7:00 and kept at a temperature of $22-23^{\circ} \mathrm{C}$. The animals were permitted free access to food and tap water. All efforts were made to minimize animal suffering and to reduce the number of animals used. 


\subsection{Preparation of focal cerebral ischemia model}

Focal cerebral ischemia was induced by middle cerebral artery occlusion (MCAO). Rats were anesthetized with a mixture of $70 \% \mathrm{~N}_{2} \mathrm{O}$ and $30 \% \mathrm{O}_{2}$ containing $2.5 \%$ isoflurane, and were maintained by the inhalation of $1.5 \%$ isoflurane during the operation. Briefly, a heatblunted black monofilament surgical suture $(4 / 0 \mathrm{G})$ was inserted into the internal carotid artery to occlude the origin of MCA. Adequacy of vascular occlusion and reperfusion was monitored in the front parietal cortex of the occluded side with a multi-channel laser Doppler flow-meter (PF5050 Q4, Perimed, Jarfalla, Sweden). Body and head temperatures were controlled at $37 \pm 0.5^{\circ} \mathrm{C}$ using a water pads. Arterial blood pressure and gases were monitored through a femoral catheter. After $60 \mathrm{~min}$ of occlusion, the filament was withdrawn to allow for reperfusion. Sham-operated (sham-op) animals were treated identically, except that MCAs were not occluded.

\subsection{Drug administration}

$\mathrm{P} 4$ was dissolved in dimethylsulfoxide (DMSO), then in sesame oil to a final concentration of $1 \%$ DMSO. P4 (4 mg/kg) was intraperitonealy (i.p.) injected. Two injections of P4 with $8 \mathrm{~h}$ interval were given starting at 1, 24, 48,72 or $96 \mathrm{~h}$ after the initiation of MCAO (post$\mathrm{MCAO}$ ). We selected this low dosage because $\mathrm{P} 4$ at this dosage is reported to significantly reduce the ischemic damage and regulate anti-apoptotic gene expression following TBI in rats (Stein, 2008). In addition, our study (Cai et al., 2008) determined that the treatment with the same dosage of P4 increases ERK1/2 phosphorylation.

To analyze the molecular mechanisms underlying the P4-actions, the P4R antagonist RU486 ( $3 \mathrm{mg} / \mathrm{kg}$ ) and the 5a-reductase inhibitor finasteride $(20 \mathrm{mg} / \mathrm{kg}$ ) (Finn et al., 2006) were given by intraperitoneal injection (i.p.) at $30 \mathrm{~min}$ before each administration of P4. The MEK inhibitor U0126 (0.5 nmol) and the PI3K inhibitor LY294002 (0.3 nmol) were injected into the cerebroventricle (i.c.v.) at $30 \mathrm{~min}$ before each injections of P4. For i.c.v. implantation, rats were anaesthetized with ketamine $(80 \mathrm{mg} / \mathrm{kg}$ i.p.). A guide cannula $(10 \mathrm{~mm}$ length, 22 gauge) aiming above the right lateral ventricle was implanted. The inhibitors or vehicle were injected with a stepper-motorized micro-syringe (Stoelting, Wood Dale, IL, USA) at a rate of $0.5 \mu \mathrm{l} / \mathrm{min}$. The drugs were prepared freshly on the day of experiment (final volume $=5 \mu \mathrm{l} / \mathrm{rat})$. Control rats were given an equal volume of vehicle.

\subsection{Histological examination}

\subsubsection{Infarct volume measuring}

Brains were removed on $7^{\text {th }}$ day post-MCAO, sectioned into 5 equidistant slices (2.0-mmthick), and incubated in a $2 \%$ 2,3,5-triphenyle-tetrazoliumchloride (TTC) solution (15 min) to visualize infarcted tissue. Measurements were performed by manually outlining the margins of the infarcted areas. Unstained areas of brain sections were defined as infarcted using the image analysis software NIH-Image 3.12. Briefly, the infarcted area on the ipsilateral side was indirectly measured by subtracting the noninfarcted area in the ipsilateral hemisphere from the total nonischaemic area of the contralateral (nonischaemic) hemisphere. Hemispheric infarcted areas were calculated separately on each coronal slice and scored from 1 to 5 , and each such area was defined as a percentage of the affected hemisphere. The infarction volume did not differ significantly across the samples in MCAOgroups $(\mathrm{P}>0.05)$. 


\subsubsection{Pyramidal cells counting}

Rats were deeply anesthetized with pentobarbital $(50 \mathrm{mg} / \mathrm{kg})$, transcardially perfused with $4 \%$ paraformaldehyde at 7 th day post-MCAO. The brains were removed, post-fixed for $24 \mathrm{~h}$, and then processed for paraffin embedding. Coronal sections (4- $\mu \mathrm{m}$-thick) including the dorsal hippocampus were cut and stained with toluidine blue. Healthy pyramidal cells showing a round cell body with a plainly stained nucleus were counted by eye using a conventional light microscope (PD70) with a 100×objective. The number of surviving CA1 pyramidal cells per $1 \mathrm{~mm}$ length along the extent of pyramidal layer were counted as neuronal density (cells/mm) (Cai et al., 2008). We also made supplemental examinations on several slices stained with trypan blue that stains dead cells, and obtained essentially the same result as that determined by eye with hematoxylin and eosin (HE) stained slices.

\subsection{Behavioral analysis}

\subsubsection{Rota rod test}

The Rota rod test was used to assess the sensorimotor coordination of rodent on $7^{\text {th }}$ day post-MCAO (see Figure 1A) using an accelerating treadmill (TSE Systems, Germany; $3 \mathrm{~cm}$ diameter). For Rota rod training sessions, animals were habituated to the Rota rod and trained to remain on the rotating drum (constant speed $6 \mathrm{rpm}$ ) for a minimum of $90 \mathrm{~s}$ to provide a preoperative baseline. Animals not achieving baseline criteria were excluded from further study. In the testing sessions, animals were placed on the Rota rod, and the rotational speed was set to accelerate from 6 to $19 \mathrm{rpm}$ over $180 \mathrm{~s}$. The latency time to fall (time on rod), namely the time when the animal first fell off the drum, was recorded.

\subsubsection{Morris Water Maze (MWM) test}

Morris water maze test was performed from $4^{\text {th }}$ day post-MCAO for consecutive 4 days (see Figure 2A) using a swimming pool (diameter: $180 \mathrm{~cm}$; height: $30 \mathrm{~cm})$ filled with water $\left(20^{\circ} \mathrm{C}\right)$ to a depth of $15 \mathrm{~cm}$. A transparent plexiglass platform $(7 \mathrm{~cm}$ in diameter) was submerged with the top located $1 \mathrm{~cm}$ below the water surface. Swimming paths were analyzed by a computer system with a video camera (AXIS-90 Target/2; Neuroscience). After reaching the platform, rat was allowed to remain on it for $30 \mathrm{sec}$. If the rat did not find the platform within $90 \mathrm{sec}$, the rat was put on the platform for $30 \mathrm{sec}$. The escape-latency to reach hiddenplatform was measured from three trials to provide a single value for each rat.

\subsection{Western blot analysis}

Rats were decapitated under deep anesthesia with ethyl ether. The hippocampus in ischemic hemisphere was taken quickly, then homogenized in a lysis buffer containing $50 \mathrm{mM}$ TriseHCl (pH 7.5), $150 \mathrm{mM} \mathrm{NaCl}, 5 \mathrm{mM}$ EDTA, $10 \mathrm{mM} \mathrm{NaF}, 1 \mathrm{mM}$ sodium orthovanadate, $1 \%$ Triton X-100, 0.5\% sodium deoxycholate, $1 \mathrm{mM}$ phenylmethylsulfonyl fluoride and protease inhibitor cocktail (Complete; Roche, Mannheim, Germany). Protein concentration was determined with BCA Protein Assay Kit (Pierce, Rochford, IL, USA). Total proteins (20 $\mu \mathrm{g}$ ) were separated by SDS-polyacrylamide gel electrophoresis (SDS-PAGE) and transferred to a polyphorylated difluoride (PVDF) membrane. The membranes were incubated with 5\% bovine serum albumin or $5 \%$ nonfat dried milk in tris-buffered saline containing $0.1 \%$ Tween 20 (TBST) for $60 \mathrm{~min}$ at room temperature, and then were incubated with a mouse monoclonal anti-phospho-ERK1/2 antibody (diluted 1:2500, Cell Signaling, Beverly, MA) at $4^{\circ} \mathrm{C}$ overnight. After being washed with TBST for three times, the membranes were 
incubated with an HRP-labeled secondary antibody, and developed using the ECL detection Kit (Amersham Biosciences, Piscataway, NJ). Following visualization, the blots were stripped by incubation in stripping buffer (Restore, Pierce Chemical Co, Rockford IL) for 5 min, re-blocked for 60 min with $5 \%$ nonfat dried milk at room temperature, then incubated with anti-total ERK1/2 (diluted 1:5000, Cell Signaling, Beverly, MA). In each experiment, levels of both ERK1/2 and phosphorelated ERK1/2 (phospho-ERK1/2) were measured in the hippocampus of ischemic hemisphere in MCAO-rats and sham-op rats (control). For each animal, phospho-ERK1/2 was normalized by respective ERK1/2 protein. Each experimental group contained 12 rats. The Western blot bands were scanned and analyzed with the image analysis software package, NIH Image.

\subsection{Data analysis/statistics}

Data were retrieved and processed with the software Microcal Origin 6.1. The group data are expressed as the means \pm standard error (SE). For comparison between two groups the 2-sided student $\mathrm{t}$-test was used. For comparison between more than 2 groups one-way analysis of variance (ANOVA) followed by the Bonferroni's post hoc test was performed. Statistical analysis was performed using the software State7 (STATA Corporation, USA). For the analysis of Morris water maze test, statistical differences were determined by an ANOVA with repeated measures, followed by the Bonferroni post hoc test. Statistical analysis was performed using the State7 software (Stata Corporation, USA). Differences at $\mathrm{P}<0.05$ were considered statistically significant.

\section{Results}

\subsection{Effective time-window of $P 4$ against ischemic brain infarct and motor dysfunction}

To examine the effects of $\mathrm{P} 4$ on ischemia-induced brain infarction, a pair of injections (i.p.) of $\mathrm{P} 4(4 \mathrm{mg} / \mathrm{kg})$ with an $8 \mathrm{~h}$ interval were given starting at $1,24,48,72$ or $96 \mathrm{~h}$ post-MCAO (Figure 1A). On $7^{\text {th }}$ day post-MCAO the results of TTC staining showed that the 60 min MCAO caused approximately $34 \%$ brain infarction mainly in the striatum and the frontoparietal cortex (Figure 1B). In comparison with vehicle-treated MCAO-rats, infarct volumes were significantly decreased by the administration of $\mathrm{P} 4$ at 1 and $24 \mathrm{~h}(\mathrm{P}<0.01$, $\mathrm{n}=12)$ or 48 and $72 \mathrm{~h}$ post-MCAO $(\mathrm{P}<0.05, \mathrm{n}=12)$, but not at $96 \mathrm{~h}(\mathrm{P}>0.05, \mathrm{n}=12)$. Similarly, the performance of rota rod test on $7^{\text {th }}$ day post-MCAO perfectly restored in MCAO-rats treated with $\mathrm{P} 4$ at $1,24,48(\mathrm{P}<0.01, \mathrm{n}=12)$ and $72 \mathrm{~h}$ post-MCAO $(\mathrm{P}<0.05, \mathrm{n}=12$; Figure $1 \mathrm{C})$ compared to vehicle-treated MCAO-rats. By contrast, $\mathrm{P} 4$ when administered at $96 \mathrm{~h}$ postMCAO had no effect on the ischemia-induced motor impairment $(\mathrm{P}>0.05, \mathrm{n}=12)$. The results indicate that the administration of $\mathrm{P} 4$ after stroke exerts a powerful neuroprotection against ischemia-induced brain damages with a wide effective time-window up to $72 \mathrm{~h}$.

\subsection{Effective time-window of P4 against ischemic death of neuronal cells and cognitive impairment}

Consistent with the previous report (Cai et al., 2008), the number of hippocampal CA1 pyramidal neurons in ischemic hemisphere decreased to approximately $50 \%$ of sham-op hemisphere on $7^{\text {th }}$ day post-MCAO $(\mathrm{P}<0.01, \mathrm{n}=8$; Figure $2 \mathrm{~B})$. To examine the effects of $\mathrm{P} 4$ on ischemia-induced death of pyramidal neurons and impairment of spatial memory, a pair of injections (i.p.) of P4 (4 mg/kg) with an $8 \mathrm{~h}$ interval was given at 1, 24, 48, 72 or $96 \mathrm{~h}$ 
A
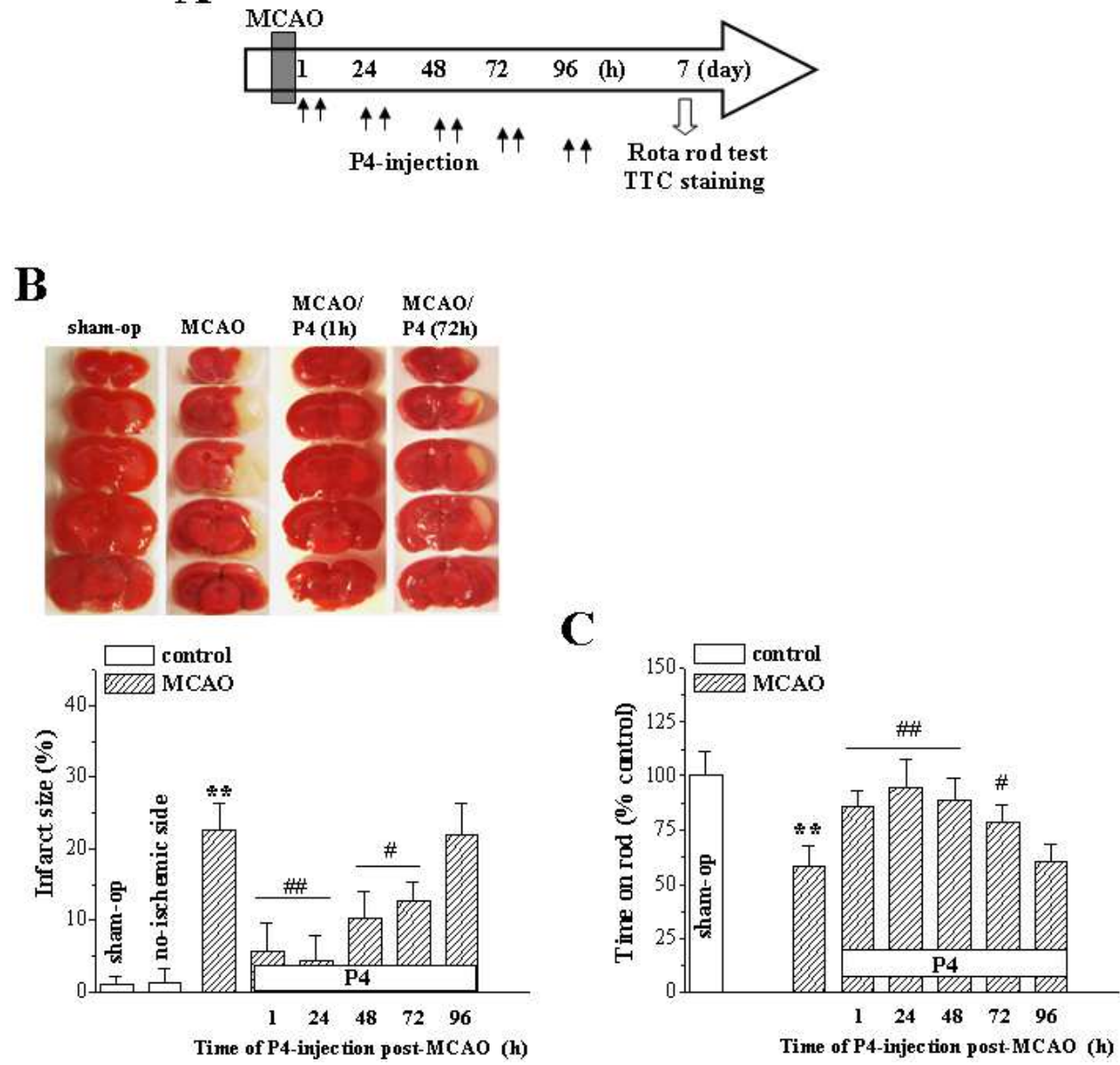

Fig. 1. Effects of P4 on ischemia-induced brain infarct and motor dysfunction. (A) Time chart of experimental procedure in Figure 1B\&C. Two injections (i.p.) of P4 (4 mg/kg) with $8 \mathrm{~h}$ interval (black arrows) were given starting at 1, 24, 48,72 or $96 \mathrm{~h}$ post-MCAO. (B) Timewindow of P4-effect against MCAO-induced brain infarct. Representative pictures of TTC-staining in sham-op rats, MCAO-rats, P4-treated MCAO-rats (upper panels). Bar graph shows the size of brain infarct that was expressed as percentage of the non-infarcted hemisphere on $7^{\text {th }}$ day post-MCAO. Horizontal hollow bar: P4 administration.

(C) Time-window of P4-effect against ischemic motor dysfunction. Bar graph shows time on rod in sham-op (open bar) and MCAO-rats (hatched bars) on $7^{\text {th }}$ day post-MCAO. ** $\mathrm{P}<0.01$ vs. sham-op rats; $\# \mathrm{P}<0.05$ and \#\#P<0.01 vs. MCAO-rats.

post-MCAO. The number of dead pyramidal cells was significantly reduced by the treatment with $\mathrm{P} 4$ at 1,24 and $48 \mathrm{~h}(\mathrm{P}<0.01, \mathrm{n}=8)$ or $72 \mathrm{~h}$ post-MCAO $(\mathrm{P}<0.05, \mathrm{n}=8)$ compared to vehicle-treated MCAO-rats. However, the administration of $\mathrm{P} 4$ at $96 \mathrm{~h}$ postMCAO exerted no significant effect in reducing the number of ischemia-induced loss of 
A

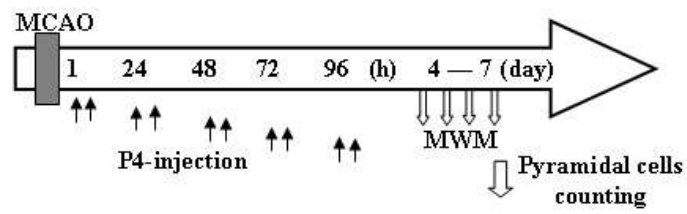

B
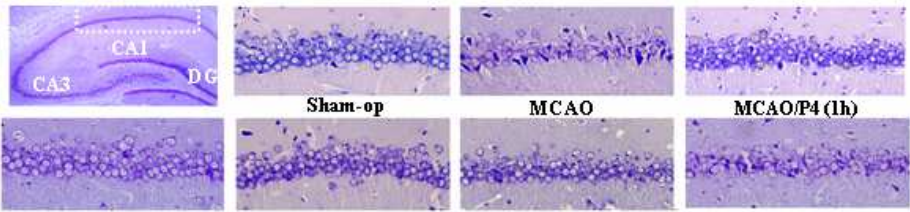

MCAO/P4 (24h)

MCAO/P4 (48h)

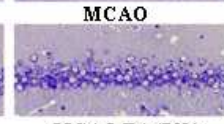

$\mathrm{MCAO} / \mathrm{P4}$ (72h)

MCAO/P4 (96h)
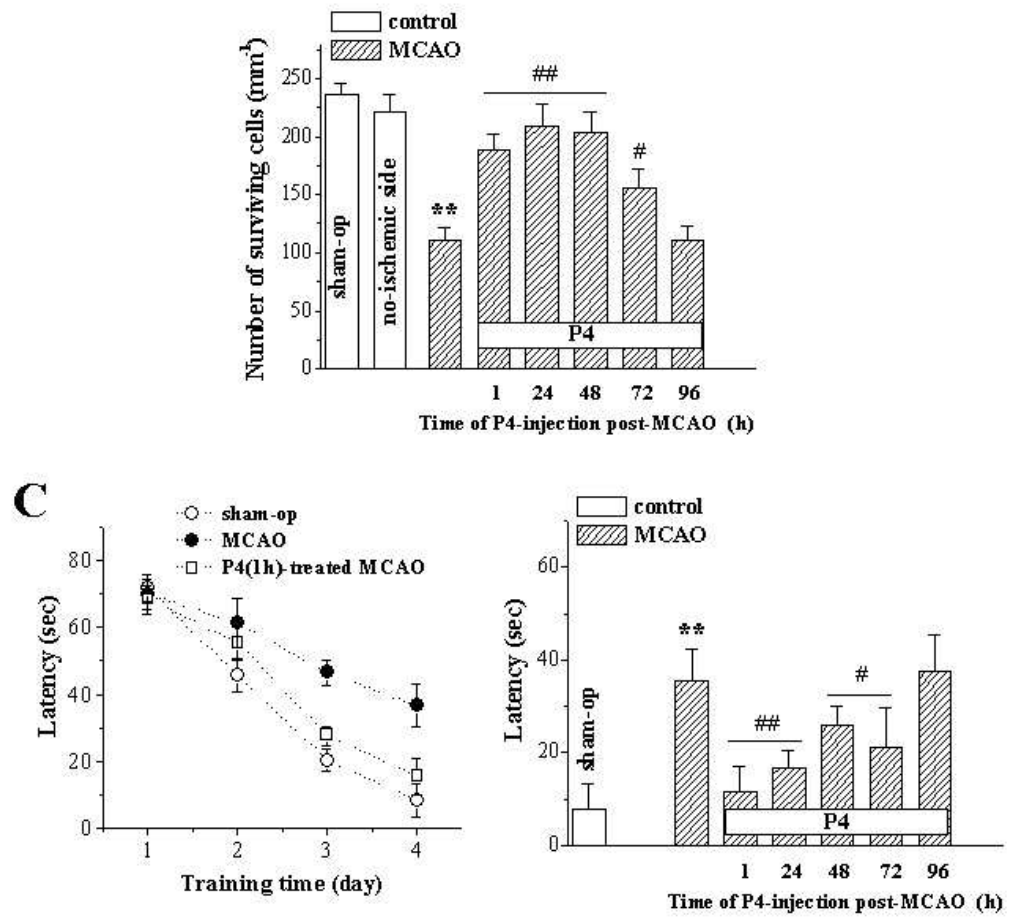

Fig. 2. Effects of $\mathrm{P} 4$ on ischemia-induced neuronal cell death and cognitive impairment.

(A) Time chart of experimental procedure in Figure 2B\&C. Two injections (i.p.) of P4 $(4 \mathrm{mg} / \mathrm{kg}$ ) with $8 \mathrm{~h}$ interval (black arrows) were given starting at 1, 24, 48, 72 or $96 \mathrm{~h}$ postMCAO. (B) Time-window of P4-effect against MCAO-induced neuronal cell death.

Representative pictures of hippocampal CA1 region in sham-op rats, MCAO-rats, P4-treated MCAO-rats (upper panels). Scale bar $=100 \mu \mathrm{m}$. Bar graph shows density of surviving neurons in the hippocampal CA1 on $7^{\text {th }}$ day post-MCAO. Horizontal hollow bar: P4 administration. (C) Time-window of P4-effect against MCAO-induced deficits in spatial memory. Typical 
trials of "Morris" water maze test (left panel) show latency (sec) to reach the hidden-platform against training time (day, day 4-7 post-MCAO) in sham-op rats, MCAO-rats, $\mathrm{P} 4$ (1h post$\mathrm{MCAO})$-treated MCAO-rats. Bar graph shows the mean latency $( \pm S E M)$ to reach the hiddenplatform on $4^{\text {th }}$ day post-training. ${ }^{* *} \mathrm{P}<0.01$ vs. sham-op rats; $\# \mathrm{P}<0.05$ and $\# \# \mathrm{P}<0.01$ vs. MCAO-rats.

pyramidal cells $(\mathrm{P}>0.05, \mathrm{n}=8)$. The $\mathrm{P} 4$ administration per se caused no observable change in CA1 pyramidal neurons on 7 th day after sham-op. Spatial learning and memory function was examined by the Morris water maze test from $4^{\text {th }}$ day post-MCAO for consecutive 4 days (Figure 2A). In comparison with sham-op rats, the escape-latency to reach the hiddenplatform on $7^{\text {th }}$ day post-MCAO increased approximately 2-fold $(\mathrm{P}<0.01, \mathrm{n}=8$; Figure $2 \mathrm{C}$ ). The behavior of acquisition performance coincided with the histological changes; the prolongation of escape-latency was perfectly improved by the treatment with P4 at 1, 24 and $48 \mathrm{~h}$ post-MCAO $(\mathrm{P}<0.01, \mathrm{n}=8)$, while was partially reduced by the injection of $\mathrm{P} 4$ at $72 \mathrm{~h}$ post-MCAO $(\mathrm{P}<0.05, \mathrm{n}=8)$. By contrast, the administration of $\mathrm{P} 4$ at $96 \mathrm{~h}$ post-MCAO failed to affect the prolonged escape-latency $(\mathrm{P}>0.05, \mathrm{n}=8)$. Both the histological and behavioral examinations here strongly suggest that the effective time-window of the neuroprotection by the $\mathrm{P} 4$ treatment is spanning from $1 \mathrm{~h}$ to $72 \mathrm{~h}$ post-MCAO. In the following sections, we describe the results on the analyses of the molecular mechanisms underlying the P4 affording neuroprotective effects on ischemia-induced death of pyramidal cells.

\subsection{P4-neuroprotection at $1 \mathrm{~h}$ post-MCAO is mediated by its metabolite ALLO}

A recent study (Ciriza et al., 2006) has revealed that the neuroprotection by P4 after ischemic brain injury is abolished by finasteride, a 5a-reductase inhibitor that inhibits the conversion of $\mathrm{P} 4$ to allopregnanolone (ALLO). To determine whether $\mathrm{P} 4$ exerts neuroprotection through its metabolite ALLO, finasteride $(20 \mathrm{mg} / \mathrm{kg}$ i.p.) was given at $30 \mathrm{~min}$ prior to every P4injection. The results showed that the pre-treatment with finasteride partially attenuated the neuroprotection of $\mathrm{P} 4$ at $1 \mathrm{~h}$ post-MCAO against MCAO-induced neuronal death $(\mathrm{P}<0.05$, $\mathrm{n}=8$; Figure $3 \mathrm{~A})$ and prolongation of escape-latency $(\mathrm{P}<0.05, \mathrm{n}=8$; Figure $3 \mathrm{~B})$, but it did not
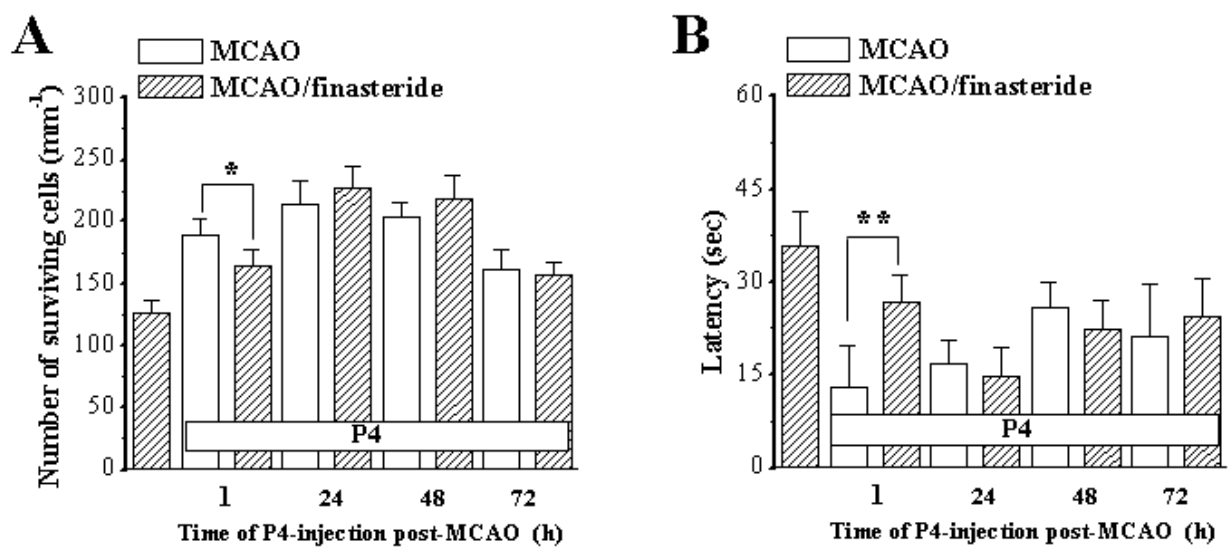

Fig. 3. Effects of finasteride, a 5a-reductase inhibitor, on the neuroprotection of P4 against MCAO-induced neuronal cell death $(\mathbf{A})$ and cognitive impairment (B). Horizontal hollow bar: P4 administration. Animals were treated with finasteride at $30 \mathrm{~min}$ before every $\mathrm{P} 4$-injection. Note that the P4-neuroprotection at $1 \mathrm{~h}$ post-MCAO is partially blocked by 
finasteride. ${ }^{*} \mathrm{P}<0.05$ and ${ }^{*} \mathrm{P}<0.01$ vs. $\mathrm{P} 4$-treated MCAO-rats at $1 \mathrm{~h}$ post-MCAO. affect the neuroprotection by $\mathrm{P} 4$ at 24,48 or $72 \mathrm{~h}$ post-MCAO $(\mathrm{P}>0.05, \mathrm{n}=8)$. The results indicate that the neuroprotection by $\mathrm{P} 4$ at $1 \mathrm{~h}$ post-MCAO is, if not all, caused by a protective action of its metabolite ALLO against ischemia-induced brain damage.

\subsection{P4-neuroprotection at 24 and $48 \mathrm{~h}$ post-MCAO is mediated by P4R activation}

The neuroprotection by $\mathrm{P} 4$ administered at $48 \mathrm{~h}$ pre-MCAO has been known to depend on P4R function (Faivre and Lange, 2007). To test this possibility in our case, the nuclear P4R blocker RU486 (3 mg/kg, i.p.) was given at $30 \mathrm{~min}$ prior to each P4 injection. The results showed that the pre-treatment with RU486 abolished the neuroprotective effects of P4 at 24 and $48 \mathrm{~h}$ post-MCAO against ischemia-induced neuronal death $(\mathrm{P}<0.01, \mathrm{n}=8$; Figure $4 \mathrm{~A})$ and spatial memory impairment $(\mathrm{P}<0.01, \mathrm{n}=8$; Figure $4 \mathrm{~B})$, whereas it failed to affect the neuroprotection by $\mathrm{P} 4$ at 1 or $72 \mathrm{~h}$ post-MCAO $(\mathrm{P}>0.05, \mathrm{n}=8)$. Meanwhile, in the absence of $\mathrm{P} 4$ the administration of RU486 at 24 or $48 \mathrm{~h}$ post-MCAO had no effect on either neuronal death $(P>0.05, n=8)$ or spatial cognitive function $(P>0.05, n=8)$. These results suggest that the neuroprotective effect of $\mathrm{P} 4$ administered at 24 and $48 \mathrm{~h}$ post-MCAO involves the P4Rmediated mechanism.
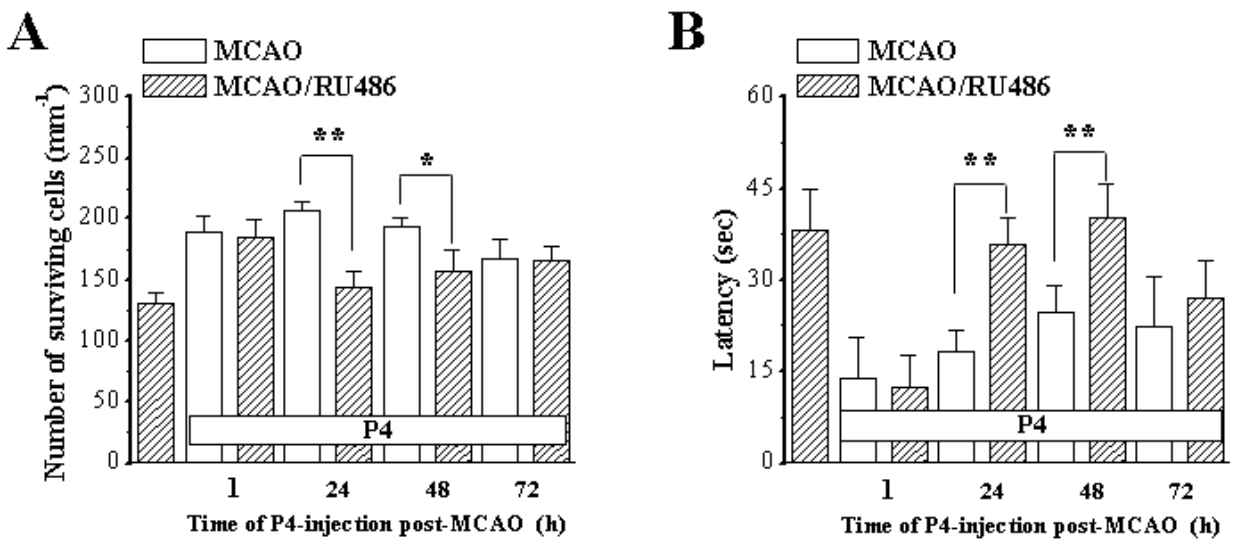

Fig. 4. Effects of RU486, a R4R antagonist, on the neuroprotection of P4 against MCAO-induced neuronal cell death (A) and cognitive impairment (B). Horizontal hollow bar: P4 administration. Animals were treated with RU486 at 30 min before every time P4-injection. Note that the P4-neuroprotection at 24 and $48 \mathrm{~h}$ post-MCAO is blocked by RU486. ${ }^{*} \mathrm{P}<0.05$ and ${ }^{*} \mathrm{P}<0.01$ vs. $\mathrm{P} 4$-treated $\mathrm{MCAO}-$ rats at 24 and $48 \mathrm{~h}$ post-MCAO.

\subsection{P4-neuroprotection at 24 and $48 \mathrm{~h}$ post-MCAO depends on P4R-ERK signaling}

As P4R-mediated ERK1/2 activation protects the ischemic brain damage (Cai et al., 2008), the experiment was designed to explore the involvement of ERK1/2 in the P4R-dependent neuroprotection after MCAO. Expectedly, the ERK kinase (MEK) inhibitor U0126 (0.3 nmol, i.c.v.) blocked the neuroprotection by $\mathrm{P} 4$ at 24 and $48 \mathrm{~h}$ against MCAO-induced neuronal death $(\mathrm{P}<0.01, \mathrm{n}=8$; Figure $5 \mathrm{~A})$ and spatial memory impairment ( $\mathrm{P} 4$ at $24 \mathrm{~h}$ post-MCAO, $\mathrm{P}<0.01, \mathrm{n}=8$; $\mathrm{P} 4$ at $48 \mathrm{~h}$ post-MCAO, $\mathrm{P}<0.05, \mathrm{n}=8$; Figure $5 \mathrm{~B})$, whereas it failed to affect the 
P4R-independent neuroprotection exerted by $\mathrm{P} 4$ administered at 1 or $72 \mathrm{~h}$ post-MCAO $(\mathrm{P}>0.05, \mathrm{n}=8)$. These results indicate that the P4R-mediated neuroprotection is highly coupled with ERK1/2 signaling pathway.

A

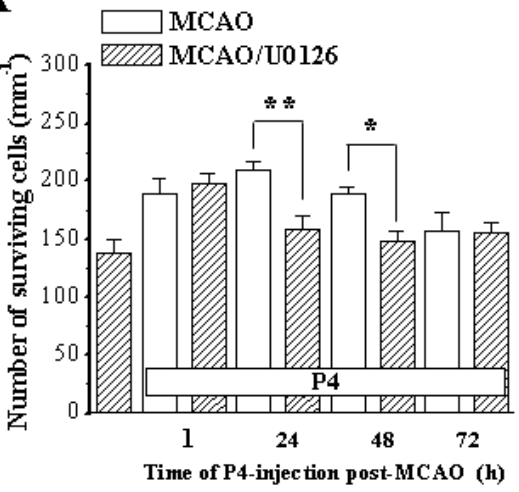

B

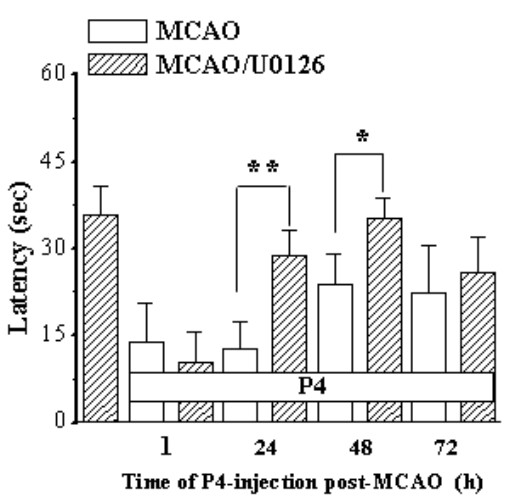

C

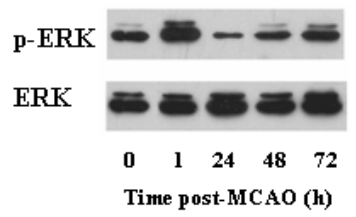

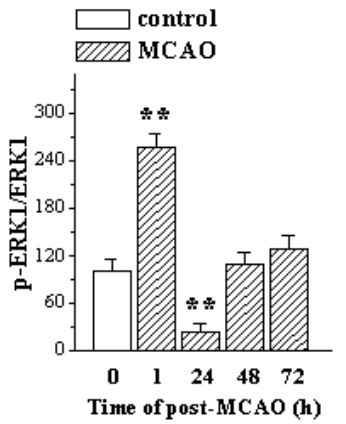

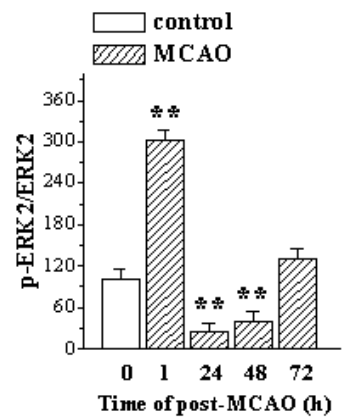

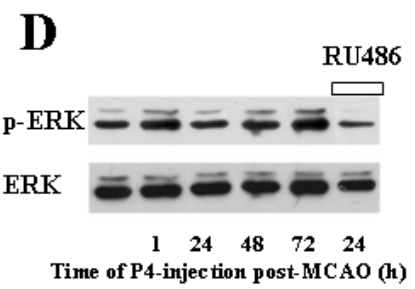

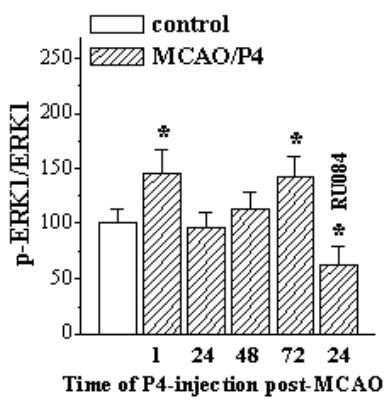

(h)

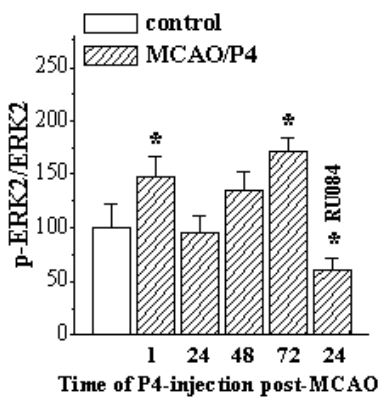

(h)

Fig. 5. Effects of U0126, a MEK inhibitor, on the neuroprotection of P4 against MCAOinduced neuronal cell death (A) and cognitive impairment (B). Horizontal hollow bar: P4 administration. Animals were treated with U0126 at 30 min before every time P4-injection. Note that the phospho-ERK1/ 2 at 24 and $48 \mathrm{~h}$ post-MCAO is blocked by U0126. ${ }^{*} \mathrm{P}<0.05$ and ${ }^{*} \mathrm{P}<0.01$ vs. $\mathrm{P} 4$-treated MCAO-rats at 24 and $48 \mathrm{~h}$ post-MCAO. (C) Kinetics of hippocampal 
phospho-ERK1/2 at 1, 24, 48 and 72 h post-MCAO. Representative western blots represent ERK1/2 phosphorylation immunoreactivity obtained from whole-cell lysates. Level of phospho-ERK1/2 is expressed as a percentage of phospho-ERK1/2 in sham-op rats. (D) Effect of P4 on phospho-ERK1/2 at 1, 24, 48 and $72 \mathrm{~h}$ post-MCAO. P4 was given at $30 \mathrm{~min}$ before harvested hippocampus. Values of phospho-ERK1/2 were normalized by phosphoERK1/2 in sham-op rats. ${ }^{*} \mathrm{P}<0.05$ and ${ }^{* *} \mathrm{P}<0.01$ vs. sham-op group; $\#<0.05$ vs. MCAO-rats treated with $\mathrm{P} 4$ at $24 \mathrm{~h}$ post-MCAO. Horizontal axis: Time of post-MCAO p4 injection.

Emerging evidence indicates that transient cerebral ischemia promotes the dephosphorylation of ERK1/2 (Jover-Mengual et al., 2007). To confirm this, kinetics of hippocampal ERK1/2 phosphorylation (phospho-ERK1/2) after MCAO was measured using Western blot analysis. In comparison with that before $\mathrm{MCAO}$, the level of phosphoERK1/ 2 was largely increased at $1 \mathrm{~h}$ post-MCAO $(\mathrm{P}<0.05, \mathrm{n}=12$; Figure $5 \mathrm{C})$, followed by a persistent decrease at $24 \mathrm{~h}$ and $48 \mathrm{~h}$ post-MCAO $(\mathrm{P}<0.05, \mathrm{n}=12)$, then returned to the basal level at $72 \mathrm{~h}$ post-MCAO $(\mathrm{P}>0.05, \mathrm{n}=12)$. To investigate the effects of $\mathrm{P} 4$ on the changes in ERK1/2 phosphorylation after MCAO, the MCAO-rats were given a single injection of $\mathrm{P} 4$ at $1,24,48$ or $72 \mathrm{~h}$ post-MCAO. Thirty minutes after the P4-injection hippocampal preparations were harvested to measure phospho-ERK1/2. As shown in Figure 5D, the treatment with P4 slightly attenuated the increased phospho-ERK1/2 at $1 \mathrm{~h}$ post-MCAO $(\mathrm{P}<0.05, \mathrm{n}=12)$, perfectly rescued the reduction of phospho-ERK1/2 at 24 and $48 \mathrm{~h}$ post-MCAO $(\mathrm{P}<0.01$, $\mathrm{n}=12)$, and elevated the level of phospho-ERK1/2 at $72 \mathrm{~h}$ post-MCAO $(\mathrm{P}<0.05, \mathrm{n}=12)$. The P4R antagonist RU486 could block the protective effect of $\mathrm{P} 4$ on the reduction of phosphoERK1/2 at $24 \mathrm{~h}$ post-MCAO ( $\mathrm{P}<0.05$ vs. P4-treated MCAO-rats, $\mathrm{n}=12$ ). These observations clearly indicate that the P4R-dependent neuroprotection against ischemia-induced brain damage is mediated, at least in part, through the regulation of ERK1/2 activity.

\subsection{P4-neuroprotection at 24-72 $\mathrm{h}$ post-MCAO requires $\mathrm{PI3K}$ signaling}

As P4 increases the level of Akt-phosphorylation, a partial process of PI3K signaling (Guerra-Araiza et al., 2009), the specific PI3K inhibitor LY294002 (0.3 nmol) was injected into the cereboventricle (i.c.v.) at $30 \mathrm{~min}$ prior to $\mathrm{P} 4$ injection to examine the involvement of PI3K-Akt signaling pathway in the P4-neuroprotection. The results showed that the pretreatment with LY294002 partially attenuated the neuroprotection of $\mathrm{P} 4$ at 24 and $48 \mathrm{~h}$ postMCAO $(\mathrm{P}<0.05, \mathrm{n}=8$; Figure 6A) and completely abolished the neuroprotection of $\mathrm{P} 4$ at $72 \mathrm{~h}$ post-MCAO $(\mathrm{P}<0.01, \mathrm{n}=8)$, whereas it had no effect on the neuroprotection of $\mathrm{P} 4$ at $1 \mathrm{~h}$ postMCAO (P>0.05, n=8). Furthermore, the pre-treatment with LY294002 blocked the P4improved impairment of spatial memory when administered at 24,48 and $72 \mathrm{~h}$ post-MCAO $(\mathrm{P}<0.05, \mathrm{n}=8$; Figure 6B). The results indicate that the PI3K-Akt signaling is involved in the P4R-dependent and P4R-independent neuroprotections by P4, depending on the timing of P4 injection.

\section{Discussion}

The present study provides evidence that the treatment with $\mathrm{P} 4$ after transient brain ischemia exerts a powerful neuroprotection with a wide effective time-window up to $72 \mathrm{~h}$ post-MCAO. The neuroprotective effects of $\mathrm{P} 4$ were mediated by different molecular mechanisms depending on the timing of $\mathrm{P} 4$ administration after ischemia. The neuroprotection by $\mathrm{P} 4$ at $1 \mathrm{~h}$ post-MCAO appeared to be caused through $\mathrm{P} 4$ 's metabolite 
allopregnanolone (ALLO) because the protection was significantly attenuated by the $5 \mathrm{a}-$ reductase inhibitor finasteride. The neuroprotection of $\mathrm{P} 4$ at 24 and $48 \mathrm{~h}$ post-MCAO appeared to be P4R-dependent through rescuing the down-regulation of ERK1/2 phosphorylation after stroke. The neuroprotective effects of $\mathrm{P} 4$ at $72 \mathrm{~h}$ post-MCAO required PI3K activation in a P4R-independent way.
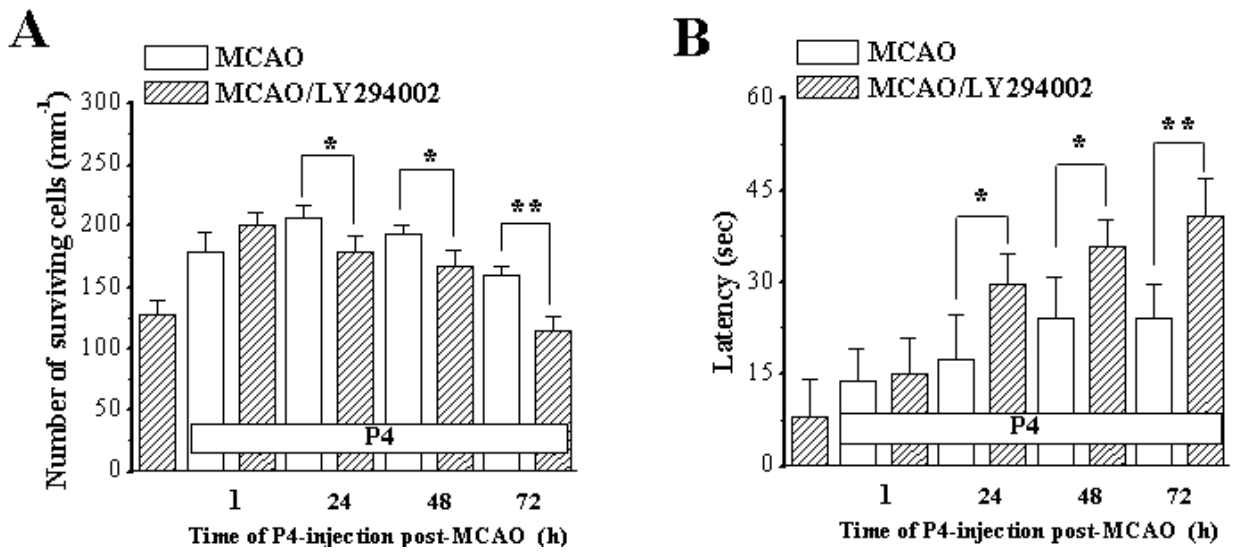

Fig. 6. Involvement of PI3K in P4-neuroprotection. Animals were treated with the specific PI3K inhibitor LY294002 (LY) at 30 min before administration of P4. Horizontal hollow bar: $\mathrm{P} 4$ administration. Note that the P4-neuroprotection at $24-72 \mathrm{hr}$ post-MCAO requires PI3K signaling. ${ }^{*} \mathrm{P}<0.05$ and ${ }^{* *} \mathrm{P}<0.01$ vs. MCAO-rats treated with $\mathrm{P} 4$ at 24,48 and 72 hr postMCAO.

\subsection{Anti-excitotoxic effect of P4's metabolite ALLO at $1 \mathrm{~h}$ after MCAO}

One recent report indicates that either P4 or ALLO when administered at $2 \mathrm{~h}$ post-MCAO is effective in reducing the infarct volume after focal brain ischemia, where ALLO shows more effective neuroprotection than its parent compound (Sayeed et al., 2007). Similarly, our results in the present study showed that the neuroprotection of $\mathrm{P} 4$ at $1 \mathrm{~h}$ post-MCAO was sensitive to the 5a-reductase inhibitor fenasteride. Thus, it is proposed that the acute neuroprotection of P4 within 1-2 h ischemia/reperfusion is caused by ALLO, a positive regulator of GABAA receptor (Belelli \& Lambert, 2005). This notion is supported by an earlier study (Ardeshiri et al., 2006) showing that the GABAA receptor antagonist picrotoxin could prevent the neuroprotection afforded by P4. The P4 neuroprotection mainly focuses on some populations of neurons that are sensitive to excitotoxicty, including the pyramidal neurons in the hippocampus and cerebral cortex, Purkinje cells in the cerebellum, as well as the neurons in the dorsal striatum and the caudate nucleus (Monnet and Maurice, 2006; Schumacher et al., 2007). Immediately after ischemia, excessive presynaptic glutamate releases result in the accumulation of extracellular glutamate to reach concentrations that induce over-activation of glutamate receptors called excitotoxicity (Jabaudon et al., 2000; Phillis and O'Regan, 2003). The process of excitotoxicity has been demonstrated in several experimental models of cerebral ischemia (Butcher et al., 1990). Therefore, it is highly likely that $\mathrm{P} 4$ and ALLO at $1 \mathrm{~h}$ post-MCAO prevent the brain injury by suppressing overexcitation of pyramidal neurons through the activation of $\mathrm{GABA}_{\mathrm{A}}$ receptors. 
However, we noted that the treatment with finasteride could not completely block the P4neuroprotection at $1 \mathrm{~h}$ post-MCAO (see Figure 3A). Excessive presynaptic glutamate releases after cerebral ischemia lead to neuronal death mainly by excessive calcium entry through N-methyl-D-aspartate receptor (NMDAr). Our recent study (Cai et al., 2008) has revealed that $\mathrm{P} 4$, as a potential $\sigma_{1}$ receptor antagonist (Monnet and Maurice, 2006), reduces $\mathrm{Ca}^{2+}$ influx across NMDAr-channels to protect hippocampal neurons from ischemia-induced cell death. In addition, at $1 \mathrm{~h}$ after brain ischemia the activation of o1 receptor by PRE-084, a $\sigma_{1}$ receptor agonist, exacerbates ischemia-induced neuronal cell death in an NMDArdependent manner ( $\mathrm{Li}$ et al., 2009). However, conflicting results have reported that the activation of $\sigma_{1}$ receptor enhances presynaptic glutamate release in the hippocampal CA1 (Meyer et al., 2002), and promotes the $\mathrm{Ca}^{2+}$ influx across NMDAr-channels (Monnet et al., 2003) and the $\mathrm{Ca}^{2+}$ efflux from calcium pools via inositol 1,4,5-trisphosphate receptors (Su and Hayashi, 2003). This discrepancy may be due to the difference in experimental condition or timing of $\mathrm{P} 4$ action. Further studies are required to directly observe the P4 effects on NMDAr-Ca ${ }^{2+}$ influx in an acute phase after stroke.

\subsection{P4R-dependent ERK activation at 24-48 $\mathrm{h}$ after stroke}

Our results revealed that the P4R-mediated ERK1/2 signaling was involved in the neuroprotection by $\mathrm{P} 4$ at $24-48 \mathrm{~h}$ post-MCAO. P4R ligand has been demonstrated to induce a transient (5-10 $\mathrm{min}$ after P4-application) activation of Src-Ras-ERK1/2 and a persistent (6-72 h) ERK1/2 activation (Faivre and Lange, 2007). Recently, Cai et al. (2008) provided in vivo evidence that $\mathrm{P} 4$ acts on $\mathrm{P} 4 \mathrm{R}$ to trigger a long-lasting ( $>48 \mathrm{hr}$ ) phosphorylation of ERK1/2, resulting in a promoted translocation of phosphorelated ERK2 into the nucleus. The translocation of ERK1/2 is a pivotal and necessary process for the activation of cAMP response element binding protein (CREB) (Nilsen and Brinton, 2003). The ERK1/2-CREB signaling has been implicated to play a critical role in the brain ischemic tolerance (Gonzalez-Zulueta et al., 2000) and neuronal cell survival (Singh, 2005; 2006). The CREB cascade can increase the expression of anti-apoptotic molecules such as Bcl-2 and BclXL (Yao et al., 2005) and decrease the expression of pro-apoptotic molecules such as Bax, Bad and caspase-3 (Djebaili et al., 2004). Consistent with the results reported by JoverMengual et al. (2007), we in the present study showed a decreased activity of ERK1/2 at 24 and $48 \mathrm{~h}$ post-MCAO. More importantly, the activation of $\mathrm{P} 4 \mathrm{R}$ at $24-48 \mathrm{~h}$ after ischemia could rescue the down-regulation of ERK1/2. Therefore, it is highly likely that the P4Rdependent neuroprotection is closely coupled with ERK1/2 signaling.

On the other hand, western blot analysis showed a transient elevation of ERK1/2 phosphorylation at $1 \mathrm{~h}$ post-MCAO. The elevation of ERK1/2 activity immediately after stroke has also been observed in humans (Slevin et al., 2000) and a rat model of cerebral ischemia (Wang et al., 2003), in which increased intracellular $\mathrm{Ca}^{2+}$ levels $\left(\left[\mathrm{Ca}^{2+}\right]_{\mathrm{i}}\right)$ after ischemia seem to lead hyper-activation of ERK1/2. Alessandrini et al. (1999) and Namura et al. (2001) provided evidence for a neuroprotective role of MEK inhibitor following transient ischemia as manifested by the reduction of infarct size and improvement of functional outcome. The neuroprotection by MEK-inhibition in ischemic brain is associated with an activation of potential anti-apoptotic pathway that suppresses caspase-3 activation and apoptosis (Wang et al., 2003). To our surprise, we observed that the treatment with P4 could attenuate the elevation of ERK1/2 phosphorylation at $1 \mathrm{~h}$ post-MCAO. Because the neuroprotection by $\mathrm{P} 4$ at $1 \mathrm{~h}$ post-MCAO was $\mathrm{P} 4 \mathrm{R}$-independent, it is proposed that $\mathrm{P} 4$ 
prevents ischemia-increased $\left[\mathrm{Ca}^{2+}\right]_{i}$ by antagonizing $\sigma_{1}$ receptor, which may stabilize the ERK1/2 activation.

\subsection{PI3K signaling is required for P4R-independent and P4R-dependnet neuroprotections}

P4 has been reported to enhance the phosphorylation of Akt/PKB (Singh et al., 2001; Kuolen et al., 2008) in the hippocampus and cerebellum (Guerra-Araiza et al., 2009). On the other hand, PI3K signaling is believed to suppress apoptotic cell death via its downstream effectors, such as Akt/PKB, to inhibit the Bcl2 family protein Bad (Noshita et al., 2001). Using the specific PI3K inhibitor LY294002, the present study provided in vivo evidence that the PI3K signaling is required for the P4-neuroprotection at $24-72 \mathrm{~h}$ post-MCAO against ischemia-induced brain damage. In human breast cancer cells, P4 induces rapid and transient activation of PI3K-Akt pathway in a P4R-dependent manner (Migliaccio et al., 1998; Castoria et al., 2001). It was reported that progestins rapidly activated PI3K-Akt pathway via P4R (Vallejo et al., 2005; Ballare et al., 2006). However, our results here showed that the PI3K-mediated neuroprotection by $\mathrm{P} 4$ administered at $72 \mathrm{~h}$ post-MCAO is P4Rindependent. P4 is reportedly to regulate PI3K signaling pathway through its metabolites (Guerra-Araiza et al., 2009), but our data determined that the neuroprotection of P4 at $24-$ $72 \mathrm{~h}$ post-MCAO was insensitive to the inhibition of 5a-reductase by fenasteride. P4-binding membrane protein 25-Dx (also known as PGRMC1) in the brain (Krebs et al., 2000; Sakamoto et al., 2004) is involved in the anti-apoptotic actions of P4 (Peluso et al., 2006, 2008). Further studies are needed to elucidate whether P4 cascades PI3K signaling after stroke through P4-binding 25-Dx mechanisms.

\subsection{Clinical significance}

P4 treatment after ischemia at relatively a low dose $(4 \mathrm{mg} / \mathrm{kg})$ exerts powerful neuroprotective effects with a wide, at least up to $72 \mathrm{~h}$ post ischemia, effective time-window, which would provide a great benefit in treating stroke. The present study provides evidence that the P4 neuroprotection has a wide effective time-window that is realized by a time dependent multiple neuroprotective mechanisms after ischemia. The results shown here not only help to understand the correlation between the declined level of P4 and the abruptly increasing incidence of stroke following the menopause, but also provide a novel the therapeutic opportunity of $\mathrm{P} 4$ against the ischemic brain injury.

\section{Acknowledgments}

This work was supported by grants for NSFC $(30872725 ; 81071027 ; 31171440)$ to Chen L.

We declare that there is no competing financial that could be construed as influencing the results or interpretation of the reported study.

\section{References}

Alessandrini A, Namura S, Moskowitz MA \& Bonventre JV. (1999). MEK1 protein kinase inhibition protects against damage resulting from focal cerebral ischemia. Proc Natl Acad Sci USA, vol. 96, pp. 12866-12869 
Ardeshiri A, Kelley MH, Korner IP, Hurn PD \& Herson PS. (2006). Mechanism of progesterone neuroprotection of rat cerebellar Purkinje cells following oxygenglucose deprivation. Eur J Neurosci, vol. 24, pp. 2567-2574

Ballare C, Vallejo G ,Vicent GP, Saragüeta P \& Beato M. (2006). Progesterone signaling in breast and endometrium. J Steroid Biochem Mol Biol vol. 102, pp. 2-10

Beato M, Herrlich P \& Schutz G. (1995). Steroid hormone receptors: many actors in search of a plot. Cell, vol. 83, pp. 851-857

Belelli D \& Lambert JJ. (2005). Neurosteroids: endogenous regulators of the GABA (A) receptor. Nat Rev Neurosci vol. 6, pp. 565-575

Boonyaratanakornkit V, Bi Y, Rudd M \& Edwards DP. (2008). The role and mechanism of progesterone receptor activation of extra-nuclear signaling pathways in regulating gene transcription and cell cycle progression. Steroids, vol. 73, pp. 922-928

Butcher SP, Bullock R, Graham DI \& McCulloch J. (1990). Correlation between amino acid release and neuropathologic outcome in rat brain following middle cerebral artery occlusion. Stroke, vol. 21, pp. 1727-1733

Cai W, Zhu Y, Furuya K, Li Z, Sokabe M \& Chen L. (2008). Two different molecular mechanisms underlying progesterone neuroprotection against ischemic brain damage. Neuropharmacology, vol. 55, pp. 127-138

Castoria G, Migliaccio A, Bilancio A, Di Domenico M, de Falco A, Lombardi M, Fiorentino R, Varricchio L, Barone MV \& Auricchio F. (2001). PI3-kinase in concert with Src promotes the S-phase entry of oestradiol-stimulated MCF-7 cells. EMBO J, vol. 20, pp. 6050-6059

Chen J, Chopp M \& Li Y. (1999). Neuroprotective effects of progesterone after transient middle cerebral artery occlusion in rat. J Neurol Sci, vol. 171, pp. 24-30

Ciriza I, Carrero P, Frye CA \& Garcia-Segura LM. (2006). Reduced metabolites mediate neuroprotective effects of progesterone in the adult rat hippocampus. The synthetic progestin medroxyprogesterone acetate (Provera) is not neuroprotective. $J$ Neurobiol, vol. 66, pp. 916-928

Djebaili M, Hoffman SW \& Stein DG. (2004). Allopregnanolone and progesterone decrease cell death and cognitive deficits after a contusion of the rat pre-frontal cortex. Neuroscience, vol. 123, pp. 349-359

Faivre EJ \& Lange CA. (2007). Progesterone receptors upregulate Wnt-1 to induce epidermal growth factor receptor transactivation and c-Src-dependent sustained activation of Erk1/2 mitogen-activated protein kinase in breast cancer cells. Mol Cell Biol, vol. 27, pp. $466-480$

Finn DA, Beadles-Bohling AS, Beckley HE, Ford MM, Gililland KR, Gorin-Meyer RE \& Wiren KM. (2006). A new look at the 5alpha-reductase inhibitor finasteride. $J$ compilation, vol. 12, pp. 53-76

Gibson CL \& Murphy SP. (2004). Progesterone enhances functional recovery after middle cerebral artery occlusion in male mice. J Cereb Blood Flow Metab, vol. 24, pp. 805-813

Gibson CL, Gray LJ, Bath PM \& Murphy SP. (2008). Progesterone for the treatment of experimental brain injury; a systematic review. Brain, vol. 13, pp. 318-328

Gonzalez-Zulueta M, Feldman AB, Klesse LJ, Kalb RG, Dillman JF, Parada LF, Dawson TM \& Dawson VL. (2000). Requirement for nitric oxide activation of p21(ras)/extracellular regulated kinase in neuronal ischemic preconditioning. Proc Natl Acad Sci USA, vol. 97, pp. 436-441 
Groswasser Z, Cohen M \& Keren O. (1998). Female TBI patients recover better than males. Brain Inj, vol. 12, pp. 805-808

Guerra-Araiza C, Amorim MA, Pinto-Almazán R, González-Arenas A, Campos MG \& Garcia-Segura LM. (2009). Regulation of the phosphoinositide-3 kinase and mitogen-activated protein kinase signaling pathways by progesterone and its reduced metabolites in the rat brain. J Neurosci Res, vol. 87, pp. 470-481

Guerra-Araiza C, Villamar-Cruz O, González-Arenas A, Chavira R \& Camacho-Arroyo I. (2003). Changes in progesterone receptor isoforms content in the rat brain during the oestrous cycle and after oestradiol and progesterone treatments. $J$ Neuroendocrinol, vol. 15, pp. 984-990

Jabaudon D, Scanziani M, Gähwiler BH \& Gerber U. (2000). Acute decrease in net glutamate uptake during energy deprivation. Proc Natl Acad Sci U S A, vol. 97, pp. 5610-5615

Jiang N, Chopp M, Stein D \& Feit H. (1996). Progesterone is neuroprotective after transient middle cerebral artery occlusion in male rats. Brain Res, vol. 30, pp. 101-107

Jover-Mengual T, Zukin RS \& Etgen AM. (2007). MAPK signaling is critical to estradiol protection of CA1 neurons in global ischemia. Endocrinology, vol. 148, pp. 1131-1143

Kannel WB, Ho K \& Thom T. (1994). Changing epidemiological features of cardiac failure. Br Heart J , vol. 72, pp. 3-9

Koulen P, Madry C,Duncan RS, Hwang JY, Nixon E, McClung N, Gregg EV \& Singh M. (2008). Progesterone potentiates IP(3)-mediated calcium signaling through Akt/PKB. Cell Physiol Biochem, vol. 21, pp. 161-172

Krebs CJ, Jarvis ED, Chan J, Lydon JP, Ogawa S \& Pfaff DW. (2000). A membrane-associated progesterone-binding protein, 25-Dx, is regulated by progesterone in brain regions involved in female reproductive behaviors. Proc Natl Acad Sci USA, vol. 97, pp. 12816-12821

Kumon Y, Kim SC, Tompkins P, Stevens A, Sakaki S \& Loftus CM. (2000). Neuroprotective effect of postischemic administration of progesterone in spontaneously hypertensive rats with focal cerebral ischemia. J Neurosurg, vol. 92, pp. 848-852

Li Z, Cui S, Zhang Z, Zhou R, Ge Y, Sokabe M \& Chen L. (2009). DHEA-neuroprotection and -neurotoxicity after transient cerebral ischemia in rats. J Cereb Blood Flow Metab, vol. 29 , pp. 287-296

Maurice T, Gregoire C \& Espallergues J. (2006). Neuro(active)steroids actions at the neuromodulatory sigma(1) receptor: Biochemical and physiological evidences, consequences in neuroprotection. Pharmacol Biochem Behav, vol. 84, pp. 581-597

Meffre D, Delespierre B, Gouézou M, Leclerc P, Vinson GP, Schumacher M, Stein DG \& Guennoun R. (2005). The membrane-associated progesterone-binding protein 25Dx is expressed in brain regions involved in water homeostasis and is up-regulated after traumatic brain injury. J Neurochem, vol. 93, pp. 1314-1326

Meyer DA, Carta M, Partridge LD, Covey DF \& Valenzuela CF. (2002). Neurosteroids enhance spontaneous glutamate release in hippocampal neurons. Possible role of metabotropic sigma1-like receptors. J Biol Chem, vol. 277, pp. 28725-28732

Migliaccio A, Piccolo D, Castoria G, Di Domenico M, Bilancio A, Lombardi M, Gong W, Beato M \& Auricchio F. (1998). Activation of the Src/p21ras/Erk pathway by progesterone receptor via cross-talk with estrogen receptor. $E M B O \mathrm{~J}$, vol. 17, pp. 2008-2018 
Monnet FP \& Maurice T. (2006). The sigma1 protein as a target for the non-genomic effects of neruo(active)steroids: molecular, physiological, and behavioral aspects. J Pharmacol Sci, vol. 100, pp. 93-118

Monnet FP, Morin-Surun MP, Leger J \& Combettes L. (2003). Protein kinase C-dependent potentiation of intracellular calcium influx by o1 receptor agonists in rat hippocampal neurons. J Pharmacol Exp Ther, vol. 307, pp. 705-712

Morali G, Letechipia-Vallejo G, Lopez-Loeza E, Montes P, Hernández-Morales L \& Cervantes M. (2005). Post-ischemic administration of progesterone in rats exerts neuroprotective effects on the hippocampus. Neurosci Lett, vol. 382, pp. 286-290

Murphy SJ, Littleton-Kearney MT \& Hurn PD. (2002). Progesterone administration during reperfusion, but not preischemia alone, reduces injury in ovariectomized rats. $J$ Cereb Blood Flow Metab, vol. 22, pp. 1181-1188

Namura S, Iihara K, Takami S, Nagata I, Kikuchi H, Matsushita K, Moskowitz MA, Bonventre JV \& Alessandrini A. (2001). Intravenous administration of MEK inhibitor U0126 affords brain protection against forebrain ischemia and focal cerebral ischemia. Proc Natl Acad Sci USA, vol. 98, pp. 11569-11574

Neubauer H, Clare SE, Wozny W, Schwall GP, Poznanovic S, Stegmann W, Vogel U, Sotlar K, Wallwiener D, Kurek R, Fehm T \& Cahill MA. (2008). Breast cancer proteomics reveals correlation between estrogen receptor status and differential phosphorylation of PGRMC1. Breast Cancer Res, vol. 15, pp. R85.

Nilsen J \& Brinton RD. (2003). Divergent impact of progesterone and medroxyprogesterone acetate (Provera) on nuclear mitogen-activated protein kinase signaling. Proc Natl Acad Sci USA, vol. 100, pp. 10506-10511

Noshita N, Lewén A, Sugawara T \& Chan PH. (2001). Evidence of phosphorylation of Akt and neuronal survival after transient focal cerebral ischemia in mice. J Cereb Blood Flow Metab, vol. 21, pp. 1442-1450

Peluso JJ, Pappalardo A, Losel R \& Wehling M. (2006). Progesterone membrane receptor component 1 expression in the immature rat ovary and its role in mediating progesterone's antiapoptotic action. Endocrinology, vol.147, pp. 3133-3140

Peluso JJ, Romak J \& Liu X. (2008). Progesterone receptor membrane component-1 (PGRMC1) is the mediator of progesterone's antiapoptotic action in spontaneously immortalized granulosa cells as revealed by PGRMC1 small interfering ribonucleic acid treatment and functional analysis of PGRMC1 mutations. Endocrinology, vol. 149, pp. 534-543

Phillis JW \& O'Regan MH. (2003). Characterization of modes of release of amino acids in the ischemic/reperfused rat cerebral cortex. Neurochem Int, vol. 43, pp. 461-467.

Sacco RL. (1998). Identifying patient populations at high risk for stroke. Neurology, vol. 51, pp. $27-30$

Sakamoto H, Ukena K, Takemori H, Okamoto M, Kawata M \& Tsutsui K. (2004). Expression and localization of 25-Dx, a membraneassociated putative progesterone-binding protein, in the developing Purkinje cell. Neuroscience, vol. 126, pp. 325-334

Sayeed I, Guo Q, Hoffman SW \& Stein DG. (2006). Allopregnanolone, a progesterone metabolite, is more effective than progesterone in reducing cortical infarct volume after transient middle cerebral artery occlusion. Ann Emerg Med, vol. 47, pp. 381-389 
Sayeed I, Wali B \& Stein DG. (2007). Progesterone inhibits ischemic brain injury in a rat model of permanent middle cerebral artery occlusion. Restor Neurol Neurosci, vol. 25, pp. 151-159

Schlesinger PH \& Saito M. (2006). The Bax pore in liposomes, Biophysics. Cell Death Differ, vol. 13, pp. 1403-1408

Schumacher M, Guennoun R, Stein DG \& De Nicola AF. (2007). Progesterone: therapeutic opportunities for neuroprotection and myelin repair. Pharmacol Ther, vol. 116, pp. 77-106

Singh M. (2001). Ovarian hormones elicit phosphorylation of Akt and extracellular-signal regulated kinase in explants of the cerebral cortex. Endocrine, vol. 14, pp. 407-415

Singh M. (2005). Mechanisms of progesterone-induced neuroprotection. Ann NY Acad Sci USA, vol. 1052, pp. 145-151

Singh M. (2006). Progesterone-induced neuroprotection. Endocrinology, vol. 29, pp. 271-274

Slevin M, Krupinski J, Slowik A, Rubio F, Szczudlik A \& Gaffney J. (2000). Activation of MAP kinase (ERK-1/ERK-2), tyrosine kinase and VEGF in the human brain following acute ischaemic stroke. Neuroreport, vol. 11, pp. 2759-2764

Stein DG. (2008). Progesterone exerts neuroprotective effects after brain injury. Brain Res Rev, vol. 57, pp. 386-397.

Su TP \& Hayashi T. (2003). Understanding the molecular mechanism of sigma-1 receptors: towards a hypothesis that sigma-1 receptors are intracellular amplifiers for signal transduction. Curr Med Chem, vol. 10, pp. 2073-2080

Thorvaldsen P, Asplund K, Kuulasmaa K, Rajakangas AM \& Schroll M. (1995). Stroke incidence, case fatality, and mortality in the WHO MONICA project. Stroke, vol. 26, pp. 361-367

Vallejo G, Ballare C, Baranao JL, Beato M \& Saragüeta P. (2005). Progestin activation of nongenomic pathways via cross talk of progesterone receptor with estrogen receptor-induces proliferation of endometrial stromal cells. Mol Endocrinol, vol. 19, pp. 3023-3037

Wang Z, Chen X, Zhou L, Wu D, Che X \& Yang G. (2003). Effects of extracellular signalregulated kinase (ERK) on focal cerebral ischemia. Chin Med J (Engl), vol. 116, pp. 1497-503

Wenger NK, Speroff L \& Packard B. (1993). Cardiovascular health and disease in women. $N$ Engl J Med, vol. 329, pp. 247-256.

Wright DW, Kellermann AL, Hertzberg VS, Clark PL, Frankel M, Goldstein FC, Salomone JP, Dent LL, Harris OA, Ander DS, Lowery DW, Patel MM, Denson DD, Gordon AB, Wald MM, Gupta S, Hoffman SW \& Stein DG. (2007). ProTECT: a randomized clinical trial of progesterone for acute traumatic brain injury. Ann Emerg Med, vol. 49, pp. 391-402

Yao XL, Liu J, Lee E, Ling GS \& McCabe JT. (2005). Progesterone differentially regulates proand anti-apoptotic gene expression in cerebral cortex following traumatic brain injury in rats. J Neurotrauma, vol. 22, pp. 656-668 


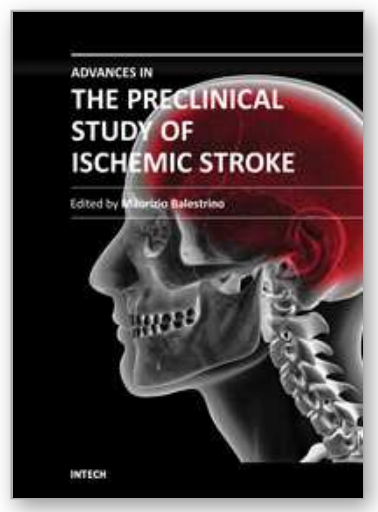

\author{
Advances in the Preclinical Study of Ischemic Stroke \\ Edited by Dr. Maurizio Balestrino
}

ISBN 978-953-51-0290-8

Hard cover, 530 pages

Publisher InTech

Published online 16, March, 2012

Published in print edition March, 2012

This book reports innovations in the preclinical study of stroke, including - novel tools and findings in animal models of stroke, - novel biochemical mechanisms through which ischemic damage may be both generated and limited, - novel pathways to neuroprotection. Although hypothermia has been so far the sole "neuroprotection" treatment that has survived the translation from preclinical to clinical studies, progress in both preclinical studies and in the design of clinical trials will hopefully provide more and better treatments for ischemic stroke. This book aims at providing the preclinical scientist with innovative knowledge and tools to investigate novel mechanisms of, and treatments for, ischemic brain damage.

\title{
How to reference
}

In order to correctly reference this scholarly work, feel free to copy and paste the following:

Weiyan Cai, Masahiro Sokabe and Ling Chen (2012). Time-Window of Progesterone Neuroprotection After Stroke and Its Underlying Molecular Mechanisms, Advances in the Preclinical Study of Ischemic Stroke, Dr. Maurizio Balestrino (Ed.), ISBN: 978-953-51-0290-8, InTech, Available from:

http://www.intechopen.com/books/advances-in-the-preclinical-study-of-ischemic-stroke/time-window-ofprogesterone-neuroprotection-after-stroke

\section{INTECH}

open science | open minds

\section{InTech Europe}

University Campus STeP Ri

Slavka Krautzeka 83/A

51000 Rijeka, Croatia

Phone: +385 (51) 770447

Fax: +385 (51) 686166

www.intechopen.com

\section{InTech China}

Unit 405, Office Block, Hotel Equatorial Shanghai

No.65, Yan An Road (West), Shanghai, 200040, China

中国上海市延安西路65号上海国际贵都大饭店办公楼 405 单元

Phone: +86-21-62489820

Fax: $+86-21-62489821$ 
(C) 2012 The Author(s). Licensee IntechOpen. This is an open access article distributed under the terms of the Creative Commons Attribution 3.0 License, which permits unrestricted use, distribution, and reproduction in any medium, provided the original work is properly cited. 